\title{
RANCANG BANGUN SISTEM PENGEMBALIAN UANG KERTAS RUPIAH PADA MESIN VENDING BERBASIS ARDUINO UNO
}

\author{
Mohammad Alifuddin \\ moh.alifuddin@gmail.com \\ STMIK Handayani Makassar
}

\begin{abstract}
Abstrak
Beberapa mesin vending saat ini belum mempunyai sistem pengembalian uang. Tujuan penelitian ini adalah membangun sebuah prototype sistem kontrol pengembalian uang kertas rupiah pada mesin vending berbasis Arduino Uno. Sensor yang digunakan untuk mendeteksi nominal dan keaslian uang adalah sensor warna TCS3200. Keaslian dan nominal uang dideteksi berdasarkan warna uang yang dimasukkan pada sistem pembaca uang. Hasil pembacaan warna uang dari sensor TCS3200 kemudian akan di proses menggunakan Arduino Uno. Nominal uang yang dideteksi pada penelitian ini adalah Rp. 20.000, Rp. 10.000 , Rp. 5.000, Rp. 2.000 dan Rp. 1.000 . Output dari sistem adalah mengontrol mekanik mesin menggunakan motor DC untuk menarik uang kertas rupiah keluar dari mesin. Sistem ini secara otomatis akan bekerja jika nominal uang yang dimasukkan oleh pembeli lebih besar dari harga barang yang di jual pada mesin vending.
\end{abstract}

Kata Kunci: Mesin vending, Uang kertas rupiah, sensor TCS3200, Arduino Uno.

\section{Abstract}

Some of the vending machines currently did not have refund systems. Purpose of this research is building a control system prototype to refund the banknote IDR money on the vending machines using Arduino Uno. The sensor was used to detect the nominal and authenticity of money is TCS3200. Authenticity and nominal of money are detected based on the money color that entered in the money reader system. The results of money detection from the TCS3200 sensor then process in the Arduino Uno. Nominal of money has detected in this research is IDR. 20,000, IDR. 10,000, IDR. 5,000 , IDR. 2,000 and IDR 1,000. The output of this system is controlling the mechanical machine using DC motor to withdraw the banknote IDR money out from the machine. The system will automatically process if the consumer entered the nominal of money is greater than from goods price on the vending machine.

Keywords: Vending machines, IDR banknotes, TCS3200 sensor, Arduino Uno.

\section{Pendahuluan}

Sistem penjualan minuman dan makanan otomatis menggunakan mesin vending telah banyak diaplikasikan, mesin-mesin tersebut banyak ditemukan di bandara-bandara, stasiun kereta, dan tempat umum lainnya. Penggunaan mesin vending untuk menjual makanan dan minuman secara otomatis akan memberikan keuntungan bagi para pengusaha karena sistem penjualannya menggunakan teknologi mesin. Mesin vending merupakan sebuah mesin otomasi yang dapat melakukan penjualan barang secara otomatis menggunakan teknik pengontrolan. Kehadiran mesin vending akan sangat membantu masyarakat dan konsumen pada saat ingin membeli suatu barang tanpa harus dibatasi oleh waktu [1]. Penelitian mengenai mesin vending telah diaplikasikan menggunakan mikrokontroler ATMega8535 [2], hasil dari penelitian tersebut adalah sistem dapat melakukan penjualan softdrink secara otomatis namun belum mempunyai sistem pengembalian uang rupiah.

Salah satu permasalahan yang ada pada mesin vending di Indonesia saat ini adalah mesin belum mempunyai sistem pengembalian uang jika nominal uang konsumen lebih besar dari harga barang [2][3][4]. Penelitian sistem pengembalian uang pada mesin vending telah dilakukan oleh peneliti sebelumnya namun dalam bentuk simulasi perangkat lunak [3]. Pada penelitian ini peneliti telah merancang desain pengembangan mesin vending dengan sistem pengembalian mata uang rupiah [4]. Hasil dari desain tersebut kemudian akan diterapkan pada sebuah rancang bangun sistem pengembalian uang kertas rupiah pada mesin vending berbasis Arduino Uno. Peneliti akan membangun sebuah prototype mesin vending dalam bentuk nyata yang dapat mengembalikan uang berdasarkan input data dari sensor warna TCS3200 dan kontrol Arduino Uno. Nominal uang yang dapat dideteksi pada penelitian ini adalah Rp. 20.000, 10.000, Rp. 5.000, Rp. 2000, dan Rp.1000, kemudian nominal pengembalian uang adalah Rp. 10.000, Rp. 5.000, Rp. 2000, dan Rp.1000. Peneliti 
ILKOM Jurnal Ilmiah Volume 11 Nomor 2 Agustus 2019

Terakreditasi peringkat 3 SK. No. 28/E/KPT/2019

menggunakan nominal uang tersebut karena hampir semua mesin vending yang ada di Indonesia bertransaksi menggunakan nominal uang dari Rp.1000 hingga Rp. 20.000.

\section{Metode}

Penelitian ini dibangun berdasarkan dari perancangan mekanik, perancangan perangkat keras, dan perancangan perangkat lunak. Perancangan mekanik meliputi pembuatan mekanik mesin penarik uang kertas, box deteksi keaslian dan nominal uang, serta prototype mesin vending. Adapun sistem mekanik yang digunakan untuk menarik uang kertas rupiah adalah menggunakan teknik mesin penarik kertas printer. Sistem mekanik penarik uang tersebut bekerja berdasarkan kecepatan putaran motor DC yang dikontrol mengunakan Arduino Uno. Pada mesin prototype terdapat empat mesin penarik uang kertas rupiah yaitu Rp. 10.000, Rp. 5.000, Rp. 2.000, dan Rp. 1.000. Pada mesin vending terdapat box yang berisi sensor TCS3200, sinar ultraviolet dan cahaya led yang berfungsi untuk mendeteksi keaslian dan nominal uang kertas rupiah. Prototype mesin vending juga mempunyai tombol harga dimana setiap tombolnya mempunyai fungsi untuk menentukan nominal harga barang yang ada pada mesin vending.

Pada perancangan perangkat keras dan perangkat lunak terdapat tiga sistem yang saling terhubung yaitu input, proses, dan output. Input pada sistem ini adalah menggunakan sensor warna TCS3200 dan enam buah tombol harga. Adapun media proses untuk mengontrol sistem ini adalah menggunakan Arduino Uno serta outputnya adalah putaran empat buah motor DC untuk menarik kembalian uang kertas rupiah dari mesin vending. Berikut adalah gambar arsitektur sistem yang dibangun pada peneltian ini, lihat gambar 1.

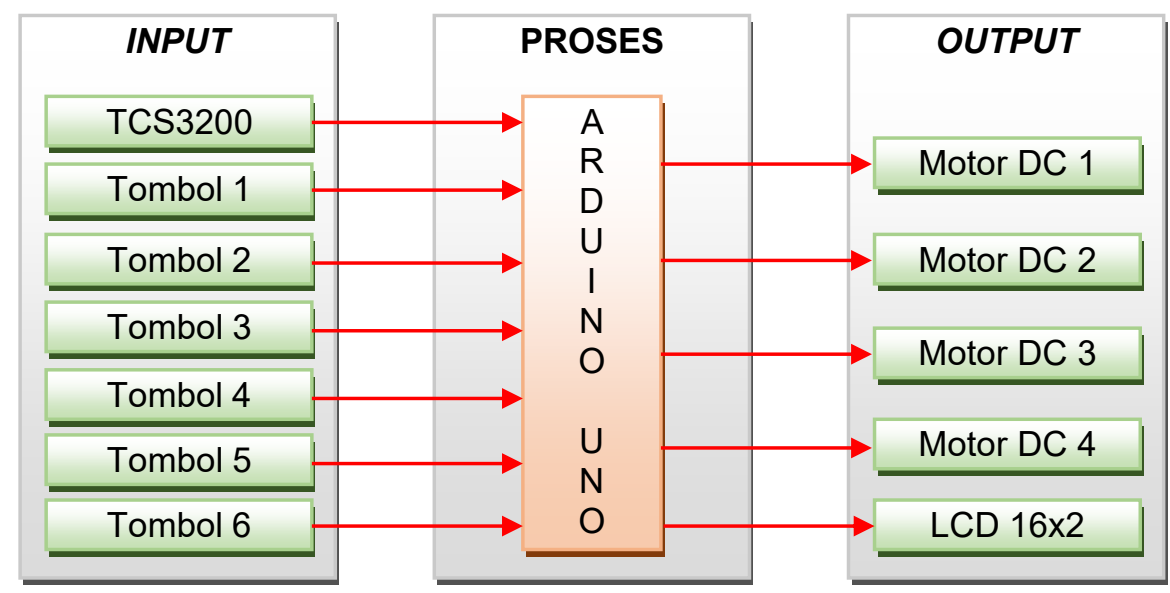

Gambar 1. Arsitektur Sistem

Sensor TCS3200 pada penelitian ini berfungsi untuk mendeteksi keaslian dan nominal uang kertas rupiah. Keaslian uang kertas rupiah dideteksi berdasarkan gambar invisible image yang akan muncul pada saat uang kertas rupiah diberi cahaya ultraviolet [5], sedangkan nominal uang kertas rupiah dideteksi berdasarkan warna [6] dimana setiap nominal uang kertas rupiah memiliki warna yang berbeda-beda. Pada saat uang dimasukkan kedalam box pembaca uang maka sistem pertama akan mendeteksi keaslian uang, jika uang asli maka sistem akan melanjutkan untuk membaca nominal uang kertas rupiah kemudian konsumen dapat melakukan transaksi untuk membeli barang. Berikut adalah gambar dan arsitektur sensor TCS3200, lihat gambar 2. 
ILKOM Jurnal Ilmiah Volume 11 Nomor 2 Agustus 2019 Terakreditasi peringkat 3 SK. No. 28/E/KPT/2019
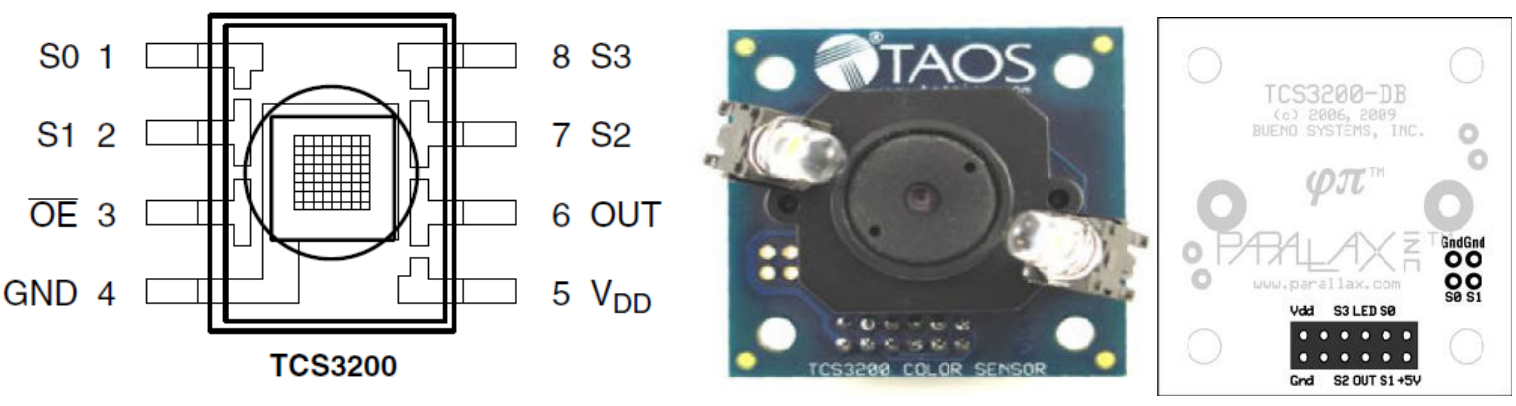

Gambar 2. Sensor TCS3200 [7][8]

Tombol pada penelitian ini berfungsi untuk menentukan nominal harga barang yang ada pada mesin vending, terdapat enam buah tombol harga yang digunakan pada prototype ini dimana setiap tombol mempunyai nominal harga yang berbeda-beda. Pada saat sistem telah mendeteksi keaslian dan nominal uang rupiah, konsumen kemudian akan menekan tombol harga barang sesuai dengan jenis barang yang tertera pada mesin vending. Setelah tombol ditekan maka Arduino Uno akan memproses untuk membandingkan nilai nominal uang dengan harga barang yang dibeli. Jika nominal uang yang dimasukkan oleh konsumen lebih besar dari harga barang maka Arduino Uno akan memerintahkan motor DC untuk berputar dan menarik uang kertas kembalian sesuai dengan harga barang yang dibeli.

Jenis Arduino Uno yang digunakan pada penelitian ini adalah Arduino Uno Rev3. Arduino merupakan sebuah board yang dilengkapi dengan mikrokontroler ATMega328PU sebagai pusat kontrolnya serta mempunyai enam pin analog input dan empat belas pin digital Input/Output. Pada penelitian ini enam pin I/O digunakan untuk membaca input sensor TCS3200, enam pin untuk membaca input tombol, dan empat pin digunakan untuk mengontrol output motor DC. Berikut adalah gambar Arduino Uno Rev3 lihat gambar 3.

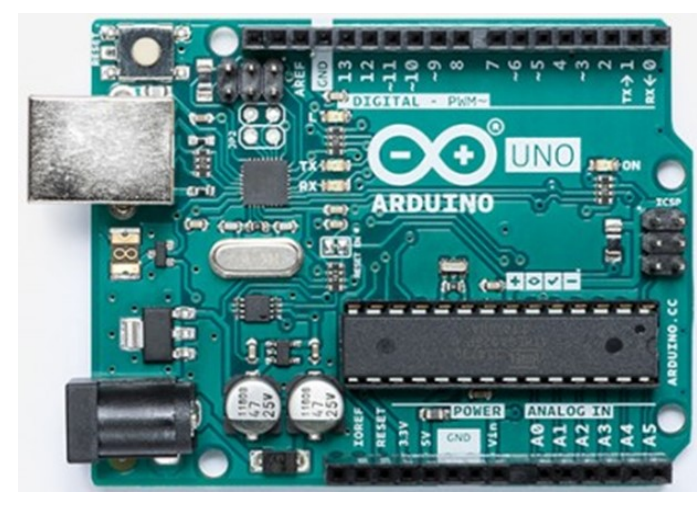

Gambar 3. Arduino Uno Rev3 [9]

Output pada sistem ini adalah putaran motor DC untuk mengerakkan mekanik mesin penarik uang kertas rupiah. Motor tersebut berputar ketika mendapat perintah dari Arduino Uno menggunakan IC Driver motor L293D. Terdapat empat buah motor DC yang digunakan dan setiap satu motor DC mengontrol satu mesin mekanik penarik uang kertas rupiah. Motor DC akan berputar hingga jumlah nominal uang kembalian keluar dari mesin sesuai dengan perintah Arduino Uno. Adapun perangkat lunak yang digunakan untuk pemrograman Arduino Uno adalah bahasa pemrograman C. Keaslian dan nominal uang kertas rupiah dideteksi menggunakan algoritma fuzzy logic, sedangkan algoritma untuk membaca input nominal harga dan jumlah pengembalian uang adalah menggunakan algoritma greedy.

\section{Hasil dan Pembahasan}

Rancang bangun sistem pengembalian uang kertas rupiah pada mesin vending menggunakan Arduino Uno telah diaplikasikan pada penelitian ini. Hasil penelitian ini adalah mesin vending dapat 


\section{ILKOM Jurnal Ilmiah Volume 11 Nomor 2 Agustus 2019}

Terakreditasi peringkat 3 SK. No. 28/E/KPT/2019

mengembalikan uang jika nominal uang yang digunakan oleh pembeli lebih besar dari harga barang. Mesin vending yang telah dibangun berukuran panjang $75 \mathrm{~cm}$, lebar $45 \mathrm{~cm}$ dan tinggi $170 \mathrm{~cm}$. Terdapat beberapa bagian yang saling terhubung pada sistem yaitu tombol yang berfungsi untuk memilih jenis barang yang akan dibeli, sensor TCS3200 untuk mendeteksi keaslian dan nominal uang kertas rupiah, cahaya ultraviolet untuk mendeteksi invisible image uang asli, LCD 16x2 untuk menampilkan pesan, Arduino Uno sebagai pusat pengolahan data, motor dc, mesin mekanik printer untuk menarik uang, power supply dan beberapa komponen elektronika lainnya.

Dalam penelitian ini mesin vending hanya dirancang untuk dapat mengembalikan uang jika nominal uang lebih besar dari harga barang. Pada saat pembeli memasukkan uang maka sensor TCS3200 akan mendeteksi keaslian dan nominal uang menngunakan algoritma fuzzy logic. Fungsi algoritma fuzzy logic adalah untuk memutuskan nilai ambang RGB (Red, Green, Blue) warna uang yang dideteksi oleh sensor TCS3200. Pada saat sensor telah mendeteksi keaslian dan nominal uang kemudian mesin menginstruksikan pembeli untuk menekan tombol jenis barang yang akan dibeli. Jika nominal uang lebih besar dari harga barang, maka mesin akan mengembalikan sisa uang pembeli menggunakan algoritma greedy. Fungsi algoritma greedy adalah untuk memutuskan jumlah nominal uang yang akan dikembalikan kepada konsumen berdasarkan jumlah nominal uang yang dideteksi dengan harga barang yang telah dibeli. Berikut adalah gambar hasil dari rancang bangun mesin vending dengan sistem pengembalian uang kertas rupiah, lihat gambar 4.

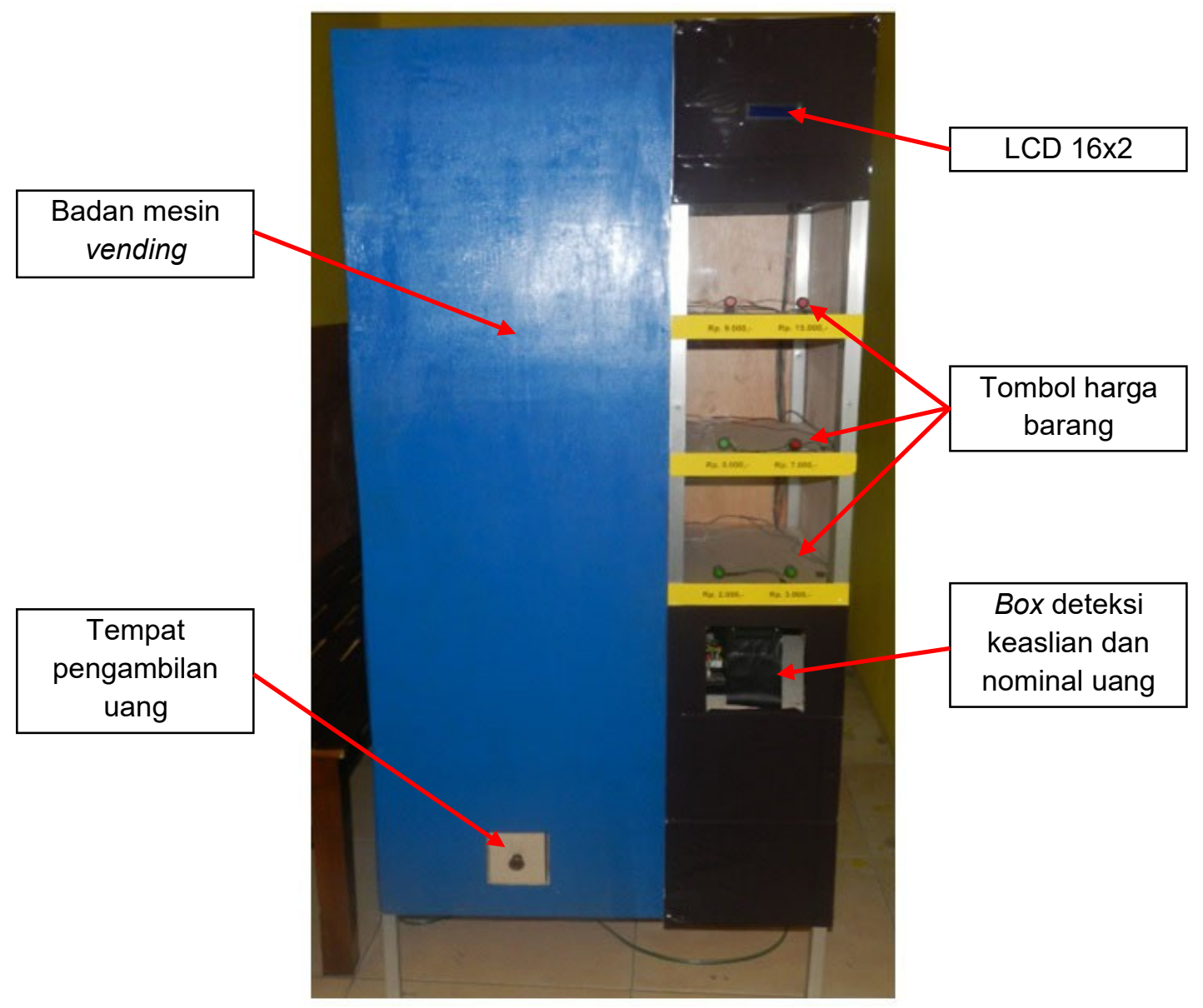

Gambar 4. Hasil perancangan mesin vending

Pada mesin vending yang telah dirancang terdapat box sebagai tempat untuk mendeteksi keaslian dan nominal uang kertas rupiah. Berikut adalah gambar box deteksi uang, lihat gambar 5 . 
ILKOM Jurnal Ilmiah Volume 11 Nomor 2 Agustus 2019

Terakreditasi peringkat 3 SK. No. 28/E/KPT/2019

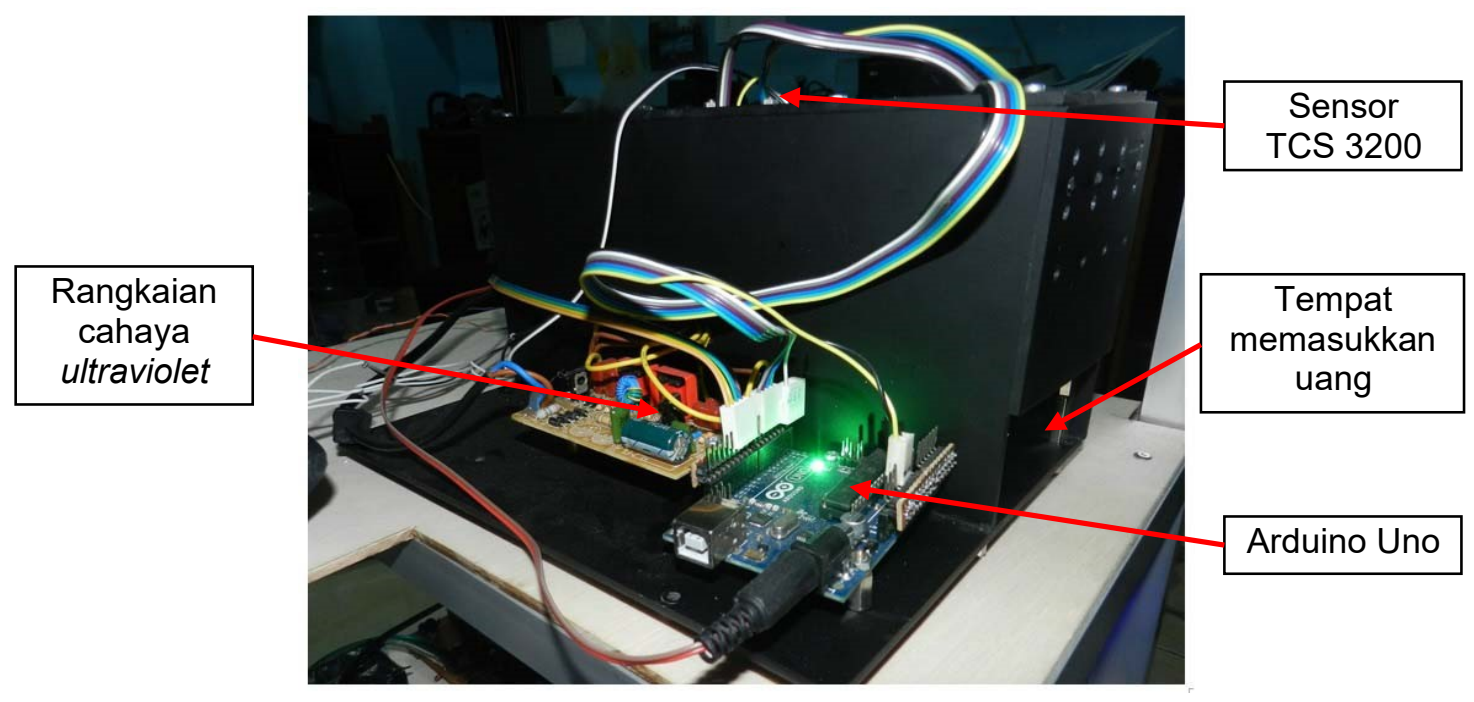

Gambar 5. Box deteksi keaslian dan nominal uang kertas rupiah

Mekanik mesin yang digunakan untuk menarik uang kertas rupiah adalah menggunakan prinsip mekanik printer. Mesin penarik uang tersebut dikontrol menggunakan putaran motor DC. Berikut adalah gambar mesin penarik uang kertas rupiah, lihat gambar 6 .

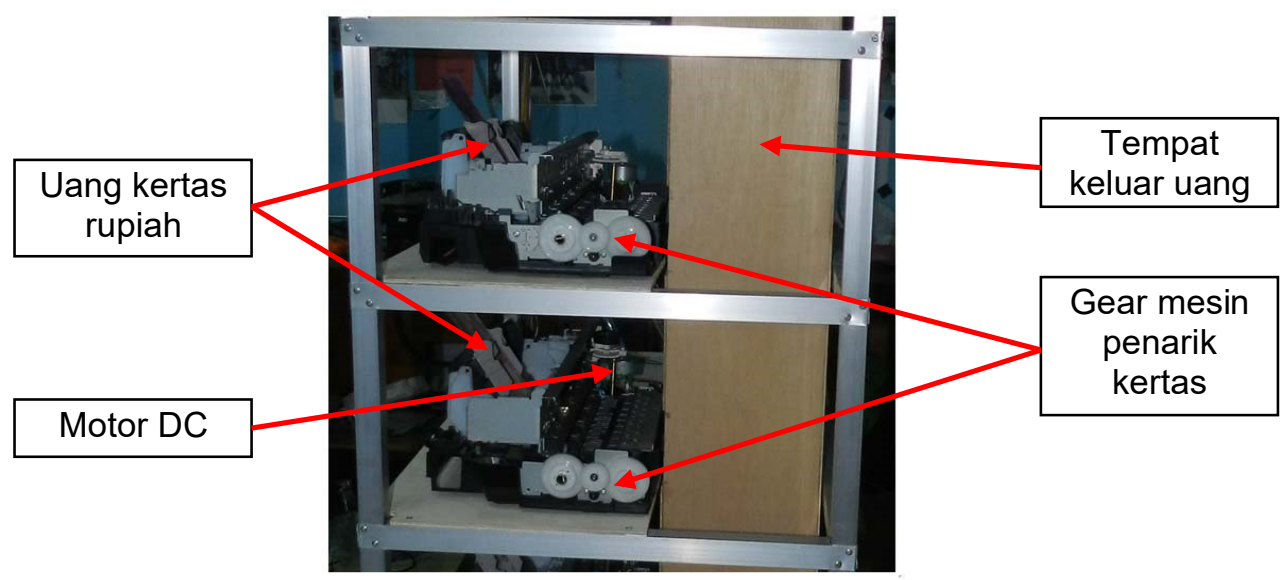

Gambar 6. Mekanik mesin penarik uang kertas rupiah

Berdasarkan hasil perancangan prototype mesin vending yang telah dibangun, berikut adalah alur proses yang dilakukan untuk mengoperasikan prototype mesin vending:

a. Masukkan uang kertas rupiah (Rp. 20.000, Rp. 10.000, Rp. 5.000, Rp. 2.000, atau Rp. 1.000.)

b. Cahaya ultraviolet menyala kemudian sensor TCS3200 mendeteksi keaslian uang, jika uang asli maka sistem akan melanjutkan mendeteksi nominal uang, jika uang palsu maka sistem berhenti.

c. Jika uang asli, sensor TCS3200 akan mendeteksi nominal uang kertas rupiah berdasarkan warna uang.

d. Setelah nominal uang dideteksi oleh sistem, tombol pilih barang akan menyala sesuai dengan harga barang.

e. Pembeli menekan tombol harga.

f. Jika nominal uang yang dimasukkan oleh pembeli lebih besar dari harga barang, maka mesin akan mengembalikan uang pembeli, dan jika uang pas maka sistem akan kembali untuk melanjutkan mendeteksi uang.

g. Proses selesai. 
ILKOM Jurnal Ilmiah Volume 11 Nomor 2 Agustus 2019 Terakreditasi peringkat 3 SK. No. $28 /$ E/KPT/2019

Pada proses pembacaan keaslian dan nominal uang, sensor TCS3200 mendeteksi warna dari uang tersebut. Data warna diambil berdasarkan nilai RGB dari warna uang, berikut adalah nilai RGB yang dideteksi berdasarkan hasil percobaan yang telah dilakukan.

Tabel 1. Nilai RGB mendeteksi keaslian uang kertas rupiah (uang asli)

\begin{tabular}{|c|c|c|c|c|c|c|}
\hline \multirow{3}{*}{ Nominal } & \multirow{3}{*}{ Perc. ke } & \multirow{3}{*}{ RGB } & \multicolumn{4}{|c|}{ Frekuensi (Khz) } \\
\hline & & & \multicolumn{2}{|c|}{ Sisi Tokoh } & \multicolumn{2}{|c|}{ Sisi Gambar } \\
\hline & & & Kanan & Kiri & Kiri & Kanan \\
\hline \multirow{7}{*}{ Rp. 20.000} & \multirow{3}{*}{1} & $\mathrm{R}$ & 1030 & 1535 & 1325 & 1810 \\
\hline & & G & 1610 & 2215 & 1880 & 2870 \\
\hline & & B & 1313 & 1866 & 2312 & 2344 \\
\hline & \multirow{4}{*}{2} & $\mathrm{R}$ & 1000 & 1505 & 1305 & 1800 \\
\hline & & $G$ & 1600 & 2205 & 1890 & 2890 \\
\hline & & B & 1343 & 1896 & 2312 & 2354 \\
\hline & & B & 1343 & 1896 & 2312 & 2354 \\
\hline \multirow{6}{*}{ Rp. 10.000} & \multirow{3}{*}{1} & $\mathrm{R}$ & 1050 & 1525 & 1315 & 1810 \\
\hline & & $\mathrm{G}$ & 1610 & 2105 & 1810 & 2810 \\
\hline & & B & 1333 & 1836 & 2322 & 2314 \\
\hline & \multirow{3}{*}{2} & $\mathrm{R}$ & 1010 & 1515 & 1315 & 1810 \\
\hline & & G & 1620 & 2225 & 1820 & 2820 \\
\hline & & B & 1333 & 1836 & 2332 & 2334 \\
\hline \multirow[b]{3}{*}{ Nominal } & \multirow[b]{3}{*}{ Perc. ke } & & \multicolumn{4}{|c|}{ Frekuensi (Khz) } \\
\hline & & & \multicolumn{2}{|c|}{ Sisi Tokoh } & \multicolumn{2}{|c|}{ Sisi Gambar } \\
\hline & & RGB & Kanan & Kiri & Kiri & Kanan \\
\hline \multirow{6}{*}{ Rp. 5.000} & \multirow{3}{*}{1} & $\mathrm{R}$ & 1010 & 1515 & 1315 & 1810 \\
\hline & & $\mathrm{G}$ & 1620 & 2225 & 1820 & 2820 \\
\hline & & B & 1333 & 1836 & 2332 & 2334 \\
\hline & \multirow{3}{*}{2} & $\mathrm{R}$ & 1040 & 1545 & 1345 & 1840 \\
\hline & & $G$ & 1610 & 2215 & 1810 & 2810 \\
\hline & & B & 1313 & 1816 & 2312 & 2314 \\
\hline \multirow{6}{*}{ Rp. 2.000} & \multirow{3}{*}{1} & $\mathrm{R}$ & 1000 & 1505 & 1305 & 1800 \\
\hline & & $G$ & 1600 & 2205 & 1890 & 2890 \\
\hline & & B & 1343 & 1896 & 2312 & 2354 \\
\hline & \multirow{3}{*}{2} & $\mathrm{R}$ & 1001 & 1503 & 1315 & 1824 \\
\hline & & $G$ & 1614 & 2245 & 1866 & 2887 \\
\hline & & B & 1000 & 1505 & 1305 & 1800 \\
\hline \multirow{6}{*}{ Rp. 1.000} & \multirow{3}{*}{1} & $\mathrm{R}$ & 1040 & 1545 & 1345 & 1840 \\
\hline & & $\mathrm{G}$ & 1610 & 2215 & 1810 & 2810 \\
\hline & & B & 1313 & 1816 & 2312 & 2314 \\
\hline & \multirow{3}{*}{2} & $\mathrm{R}$ & 1020 & 1525 & 1325 & 1820 \\
\hline & & $G$ & 1610 & 2225 & 1810 & 2820 \\
\hline & & B & 1343 & 1866 & 2332 & 2364 \\
\hline
\end{tabular}

Tabel 2. Nilai RGB deteksi uang palsu (print kertas yang menyerupai uang rupiah)

\begin{tabular}{|c|c|c|c|c|c|c|}
\hline \multirow{3}{*}{ Nominal } & \multirow{3}{*}{ Perc. ke } & \multirow{3}{*}{ RGB } & \multicolumn{4}{|c|}{ Frekuensi (Khz) } \\
\hline & & & \multicolumn{2}{|c|}{ Sisi Tokoh } & \multicolumn{2}{|c|}{ Sisi Gambar } \\
\hline & & & Kanan & Kiri & Kiri & Kanan \\
\hline \multirow{8}{*}{ Rp. 20.000} & \multirow{3}{*}{1} & $\mathrm{R}$ & 1543 & 1776 & 2032 & 1865 \\
\hline & & G & 5383 & 5734 & 6785 & 7034 \\
\hline & & $\mathrm{B}$ & 4965 & 5543 & 6735 & 6674 \\
\hline & \multirow{3}{*}{2} & $\mathrm{R}$ & 1500 & 1700 & 2000 & 1800 \\
\hline & & $G$ & 5300 & 5700 & 6700 & 7021 \\
\hline & & $\mathrm{B}$ & 4987 & 5567 & 6773 & 6654 \\
\hline & \multirow[b]{2}{*}{1} & $\mathrm{R}$ & 1520 & 1710 & 2020 & 1830 \\
\hline & & $G$ & 5320 & 5750 & 6730 & 7041 \\
\hline
\end{tabular}


ILKOM Jurnal Ilmiah Volume 11 Nomor 2 Agustus 2019 Terakreditasi peringkat 3 SK. No. 28/E/KPT/2019

\begin{tabular}{|c|c|c|c|c|c|c|}
\hline \multirow[t]{4}{*}{ Rp. 10.000} & & $B$ & 4937 & 5557 & 6733 & 6654 \\
\hline & \multirow{3}{*}{2} & $\mathrm{R}$ & 1535 & 1734 & 2022 & 1823 \\
\hline & & G & 5311 & 5734 & 6754 & 7076 \\
\hline & & $B$ & 4926 & 5565 & 6732 & 6637 \\
\hline \multirow{6}{*}{ Rp. 5.000} & \multirow{3}{*}{1} & $\mathrm{R}$ & 1543 & 1776 & 2032 & 1865 \\
\hline & & G & 5383 & 5734 & 6785 & 7034 \\
\hline & & $B$ & 4965 & 5543 & 6735 & 6674 \\
\hline & \multirow{3}{*}{2} & $\mathrm{R}$ & 1500 & 1700 & 2000 & 1800 \\
\hline & & $G$ & 5300 & 5700 & 6700 & 7021 \\
\hline & & $B$ & 4987 & 5567 & 6773 & 6654 \\
\hline \multirow{6}{*}{ Rp. 2.000} & \multirow{3}{*}{1} & $\mathrm{R}$ & 1500 & 1700 & 2000 & 1800 \\
\hline & & G & 5300 & 5700 & 6700 & 7021 \\
\hline & & $B$ & 4987 & 5567 & 6773 & 6654 \\
\hline & \multirow{3}{*}{2} & $\mathrm{R}$ & 1512 & 1757 & 2054 & 1832 \\
\hline & & G & 5326 & 5773 & 6774 & 7034 \\
\hline & & B & 4965 & 5553 & 6764 & 6683 \\
\hline \multirow{6}{*}{ Rp. 1.000} & \multirow{3}{*}{1} & $\mathrm{R}$ & 1520 & 1710 & 2020 & 1830 \\
\hline & & $G$ & 5320 & 5750 & 6730 & 7041 \\
\hline & & $B$ & 4937 & 5557 & 6733 & 6654 \\
\hline & \multirow{3}{*}{2} & $\mathrm{R}$ & 1535 & 1734 & 2022 & 1823 \\
\hline & & $\mathrm{G}$ & 5311 & 5734 & 6754 & 7076 \\
\hline & & $B$ & 4926 & 5565 & 6732 & 6637 \\
\hline
\end{tabular}

Tabel 3. Nilai RGB mendeteksi nominal uang kertas rupiah (uang asli)

\begin{tabular}{|c|c|c|c|c|c|c|}
\hline \multirow{3}{*}{ Nominal } & \multirow{3}{*}{ Perc. ke } & \multirow{3}{*}{ RGB } & \multicolumn{4}{|c|}{ Frekuensi (Khz) } \\
\hline & & & \multicolumn{2}{|c|}{ Sisi Tokoh } & \multicolumn{2}{|c|}{ Sisi Gambar } \\
\hline & & & Kanan & Kiri & Kiri & Kanan \\
\hline \multirow{9}{*}{ Rp. 20.000} & \multirow{3}{*}{1} & $\mathrm{R}$ & 1789 & 2533 & 2556 & 2879 \\
\hline & & G & 3974 & 3345 & 3242 & 3454 \\
\hline & & B & 4654 & 5343 & 5435 & 4976 \\
\hline & \multirow{3}{*}{2} & $\mathrm{R}$ & 1732 & 2634 & 2543 & 2537 \\
\hline & & $\mathrm{G}$ & 9876 & 8363 & 9676 & 8797 \\
\hline & & $B$ & 4653 & 5955 & 5644 & 4855 \\
\hline & \multirow{3}{*}{3} & $\mathrm{R}$ & 1956 & 2745 & 2965 & 2367 \\
\hline & & $\mathrm{G}$ & 3486 & 3855 & 3536 & 3454 \\
\hline & & B & 4634 & 5363 & 5433 & 4975 \\
\hline \multirow{9}{*}{ Rp. 10.000} & \multirow{3}{*}{1} & $\mathrm{R}$ & 3982 & 3345 & 2865 & 3879 \\
\hline & & $\mathrm{G}$ & 10434 & 11232 & 10454 & 10967 \\
\hline & & B & 4907 & 5123 & 5113 & 4877 \\
\hline & \multirow{3}{*}{2} & $\mathrm{R}$ & 3985 & 3325 & 2825 & 3859 \\
\hline & & $\mathrm{G}$ & 10454 & 11267 & 10442 & 10943 \\
\hline & & $B$ & 4933 & 5195 & 5142 & 4644 \\
\hline & \multirow{3}{*}{3} & $\mathrm{R}$ & 3996 & 3335 & 2867 & 3647 \\
\hline & & $\mathrm{G}$ & 10211 & 11242 & 10154 & 10267 \\
\hline & & B & 4902 & 5143 & 5123 & 4827 \\
\hline \multirow{10}{*}{ Rp. 5.000} & \multirow{3}{*}{1} & $\mathrm{R}$ & 3467 & 3965 & 3758 & 3352 \\
\hline & & G & 11987 & 12132 & 11323 & 11434 \\
\hline & & B & 4654 & 4547 & 4865 & 4654 \\
\hline & \multirow{3}{*}{2} & $\mathrm{R}$ & 3441 & 3945 & 3758 & 3352 \\
\hline & & $\mathrm{G}$ & 11447 & 12123 & 11344 & 11432 \\
\hline & & $B$ & 4654 & 4517 & 4854 & 4644 \\
\hline & \multirow{4}{*}{3} & $\mathrm{R}$ & 3462 & 3963 & 3748 & 3354 \\
\hline & & $\mathrm{G}$ & 11982 & 12122 & 11223 & 11634 \\
\hline & & B & 4664 & 4527 & 4835 & 4654 \\
\hline & & $\mathrm{R}$ & 3654 & 3876 & 3966 & 3323 \\
\hline
\end{tabular}


ILKOM Jurnal Ilmiah Volume 11 Nomor 2 Agustus 2019 Terakreditasi peringkat 3 SK. No. 28/E/KPT/2019

\begin{tabular}{|c|c|c|c|c|c|c|}
\hline \multirow{8}{*}{ Rp. 2.000} & \multirow[t]{2}{*}{1} & G & 14756 & 14965 & 14856 & 14556 \\
\hline & & $B$ & 5978 & 6123 & 6221 & 5876 \\
\hline & \multirow{3}{*}{2} & $\mathrm{R}$ & 3624 & 3846 & 3961 & 3326 \\
\hline & & G & 14766 & 14915 & 14826 & 14552 \\
\hline & & $B$ & 5976 & 6121 & 6225 & 5873 \\
\hline & \multirow{3}{*}{3} & $\mathrm{R}$ & 3614 & 3872 & 3936 & 3323 \\
\hline & & G & 14716 & 14961 & 14836 & 14534 \\
\hline & & $B$ & 5971 & 6223 & 6421 & 5776 \\
\hline \multirow{9}{*}{ Rp. 1.000} & \multirow{3}{*}{1} & $\mathrm{R}$ & 3543 & 3455 & 3865 & 3745 \\
\hline & & G & 12969 & 13123 & 12978 & 12867 \\
\hline & & $B$ & 4789 & 4987 & 5123 & 5344 \\
\hline & \multirow{3}{*}{2} & $\mathrm{R}$ & 3513 & 3435 & 3845 & 3725 \\
\hline & & G & 12949 & 13125 & 12935 & 12817 \\
\hline & & $B$ & 4784 & 4933 & 5123 & 5344 \\
\hline & \multirow{3}{*}{3} & $\mathrm{R}$ & 3543 & 3455 & 3865 & 3375 \\
\hline & & G & 12929 & 13323 & 12938 & 1247 \\
\hline & & $B$ & 4782 & 4937 & 5173 & 5234 \\
\hline
\end{tabular}

Pada tabel 1 memperlihatkan nilai warna RGB yang dideteksi oleh sensor TCS3200 pada saat sistem mendeteksi keaslian uang kertas rupiah, tabel 2 memperlihatkan nilai warna RGB yang dideteksi pada saat sistem mendeteksi uang palsu, dan tabel 3 memperlihatkan nilai warna RGB yang dideteksi pada saat sistem mendeteksi nominal uang kertas rupiah. Pada uang kertas rupiah terdapat dua sisi yaitu sisi tokoh dan sisi gambar, sisi pada setiap nominal uang kertas rupiah mempunyai nilai warna RGB yang berbeda-beda sehingga dibutuhkan algoritma fuzzy logic untuk memutuskan nilai ambang yang tepat dalam menentukan keaslian dan nominal uang kertas rupiah.

Tabel 4. Daftar kembalian uang berdasarkan harga barang.

\begin{tabular}{ccccccc} 
Nominal & \multicolumn{7}{c}{ Harga Barang (Rp.) } \\
\cline { 2 - 7 } & $\mathbf{1 5 . 0 0 0}$ & $\mathbf{1 1 . 0 0 0}$ & $\mathbf{7 . 0 0 0}$ & $\mathbf{5 . 0 0 0}$ & $\mathbf{3 . 0 0 0}$ & $\mathbf{2 . 0 0 0}$ \\
Rp. 20.000 & 5.000 & 11.000 & 13.000 & 15.000 & 17.000 & 18.000 \\
Rp. 10.000 & - & - & 3.000 & 5.000 & 7.000 & 8.000 \\
Rp. 5.000 & - & - & - & - & 2.000 & 3.000
\end{tabular}

Tabel 5. Pembacaan nominal uang dari sepuluh percobaan

\begin{tabular}{lcccccc}
\hline NOMINAL & $\begin{array}{c}\text { Baca } \\
\text { Rp.20.000 }\end{array}$ & $\begin{array}{c}\text { Baca } \\
\text { Rp.10.000 }\end{array}$ & $\begin{array}{c}\text { Baca } \\
\text { Rp.5.000 }\end{array}$ & $\begin{array}{c}\text { Baca } \\
\text { Rp.2.000 }\end{array}$ & $\begin{array}{c}\text { Baca } \\
\text { Rp.1.000 }\end{array}$ & Error \\
\hline Rp.20.000 & 10 & - & - & - & - & 0 \\
Rp.10.000 & - & 10 & - & - & - & 0 \\
Rp.5.000 & - & - & 10 & - & - & 0 \\
Rp.2.000 & - & - & - & 10 & - & 0 \\
Rp.1.000 & - & - & - & - & 8 & 2 \\
\hline
\end{tabular}

Pada tabel 4 dapat dilihat bahwa jika nominal uang yang dimasukkan oleh pembeli lebih besar dari harga barang maka mesin akan mengembalikan uang sesuai dengan nominal uang dan harga barang. Algoritma yang digunakan untuk menentukan jumlah pengembalian uang kertas rupiah adalah algoritma greedy. Dalam penelitian ini uji coba pembacaan nominal uang kertas rupiah telah dilakukan, tabel 5 memperlihatkan hasil uji coba pembacaan nominal uang kertas rupiah dengan tingkat error hingga $2 \%$.

\section{Kesimpulan dan Saran}

Rancang bangun sistem pengembalian uang kertas rupiah pada mesin vending berbasis Arduino Uno telah diaplikasikan pada penelitian ini. Nominal uang yang dideteksi oleh mesin vending adalah Rp. 20.000 , Rp. 10.000 , Rp. 5.000 , Rp. 2.000, dan Rp. 1.000 , sedangkan nominal pengembalian adalah Rp. 10.000 , Rp. 5.000, Rp. 2.000, dan Rp. 1.000. Sistem dapat mendeteksi keaslian dan nominal uang kertas rupiah berdasarkan warna RGB uang menggunakan sensor TCS3200 dan diproses menggunakan algoritma fuzzy logic. Keaslian uang kertas rupiah dideteksi 
ILKOM Jurnal Ilmiah Volume 11 Nomor 2 Agustus 2019

Terakreditasi peringkat 3 SK. No. 28/E/KPT/2019

berdasarkan invisible image yang ditampilkan oleh uang kertas menggunakan cahaya ultraviolet sedangkan nominal uang dideteksi berdasarkan warna uang kertas rupiah. Mesin vending yang telah dirancang dapat mengembalikan uang pembeli jika nominal uang lebih besar dari harga barang menggunakan algoritma greedy. Saran untuk penelitian kedepannya adalah pembacaan keaslian dan nominal uang dapat ditingkatkan kecepatannya agar sistem dapat bekerja secara maksimal serta diharapkan kedepannya mesin dapat mengembalikan uang dalam bentuk koin.

\section{Daftar Pustaka}

[1] A. Purnomo, "Perancangan dan Pembuatan Mesin Penjual Makanan Otomatis Menggunakan Relai Cerdas," Karya ilmiah Jurusan Teknik Elektro Fakultas Teknik Universitas Muhammadiyah Surakarta, 2015.

[2] D. S. Adiputra, Y. Palapa, H. Subagiyo, "Mesin Penjual Softdrink Otomatis Berbasis ATMega8535," Jurnal ELEMENTER. vol. 1, no. 2, 2015.

[3] Alamsyah, I. T. Putri, "Penerapan Algoritma Greedy Pada Mesin Penjual Otomatis (Vending Machine)," Scientific Journal of Informatics, vol. 1, vo. 2, 2014.

[4] M. Alifuddin, "Pengembangan Mesin Vending Dengan Sistem Pengembalian Mata Uang Rupiah,” Jurnal IT: Media Informasi STMIK Handayani Makassar, vol. 15, 2014.

[5] A. Jalil, "Pengolahan Citra Mendeteksi Keaslian Uang Kertas Rupiah Menggunakan Raspberry Pi," Jurnal IT STMIK Handayani, vol. 14, pp. 28-40, 2014.

[6] A. Jalil, "Sistem Kontrol Mesin Penukaran Uang Kertas Rupiah Berbasis Pengolahan Citra dan Raspberry Pi," ILKOM Jurnal IImiah Volume 10 Nomor 2, pp. 128 - 135, 2018. DOI: http://dx.doi.org/10.33096/ilkom.v10i2.272.128-135.

[7] Texas Advanced Optoelectronic Solutions Inc, "TCS3200, Tcs3210 Programmable Color LightTo-Frequency Converter," Datasheet, TAOS099, 2009.

[8] A. R. Pratama dan R. Adil, "Desain Mekanik Alat Bantu Identifikasi Susu dan Sari Buah Dengan Menggunakan Sensor Warna TCS 3200," EEPIS Final Project, 2010.

[9] https://store.arduino.cc/usa/arduino-uno-rev3 [online], diakses tanggal 12 Februari 2019. 